Biological and Clinical Sciences Research Journal

ISSN: 2708-2261

www.bcsrj.com

DOI: https://doi.org/10.54112/bcsri.v2021i1.51

Biol. Clin. Sci. Res. J., Volume, 2020: 51

MEDEYE

Original Research Article

\title{
PERCEPTION REGARDING SELF-MEDICATION OF ANTIBIOTICS IN GENERAL PUBLIC SECTOR UNIVERSITY OF SOUTHERN PUNJAB: A COMPARISON BETWEEN MEDICAL AND NON- MEDICAL STUDENTS
}

\author{
KHALID S, ALI Q, *HAFEEZ MM, MALIK A \\ Institute of Molecular Biology and Biotechnology, The University of Lahore, Lahore, Pakistan \\ Corresponding author email: mansoorhafeez140@gmail.com
}

(Received, $17^{\text {th }}$ March 2020, Revised $20^{\text {th }}$ January 2020, Published $23^{\text {rd }}$ January 2021)

\begin{abstract}
Self-medication with antibiotics is a most rapidly emerging problem especially in developing countries like Pakistan. Antibiotics are easily accessible to the general public without consulting any practitioner even without prescriptions. So there are many risks linked to the inappropriate use of antibiotics. The main aim of this study was to assess the wrong practice of self-medication in public sector universities of southern Punjab. The current study also compares the self-medication practices in various departments of universities. A validated questionnaire was used to collect data. Descriptive statistics were used to analyze the data and inferential statistics (chi-square test). The study was included data from 900 students including both males and females from various departments. Among 900 students, 450 students of medical while 450 were non-medical students. Frequency of selfmedication was found to $57 \%$. The antibiotics more frequently use for self-medication were Augmentin (37 \%), Amoxicillin (23\%). Fever and cough were the most frequent indication for the use of self-medicated antibiotics. Because of their sufficient knowledge of pharmacology, most students were self-medicated (40\%). Academic knowledge is the principal source of antibiotic information (60\%). Just (39\%) of the students thought that selfmedication is part of the self-core, $31 \%$ of the students perceived that the availability of non-prescription drugs could prevent the growing trend of self-medication with antibiotics. $30 \%$ of students perceived that antibiotics were aware of the harms of self-medication or informed about them. Based on this study, it can be concluded that a high proportion of medical students and non-medical students use antibiotics without medical prescription and such practices are more common in the general public sector.
\end{abstract}

Keywords: self-medication, antibiotics, pharmacology, drugs, Augmentin, Amoxicillin

\section{Introduction}

Several problems such as antimicrobial resistance, are caused by excessive and unfair use of antibiotics is one of the major concerns worldwide. This inappropriate use of antibiotics resulting in bacterial resistance. Bacterial resistance endorsing more financial burden because of multiple expensive antibiotics use. Because of expensive treatment for resistant bacteria low-class population is unable to afford hence many precious lives are being lost (Smith et al., 2001). In different countries, antibiotic consumption varies: higher rates are observed in South European countries and lower rates are observed in Northern European countries (Goossens et al., 2005). Reported data from research indicates that up to $50 \%$ of hospital antibiotic usage is excessive (Davey et al., 2006). However, the main antibiotic load comes from the primary health care stage. Research from different countries shows that $75-94 \%$ of all antibiotics are directly used by ambulatory patients (Picazo et al., 2003). There is a strong inclination for overuse of antibiotics due to their extensive use in the treatment of viral and selflimiting bacterial diseases. The favoured use of broad-spectrum antibiotics is often baseless (Bronzwaer, 2002; Johnston, 1998; Lipsitch and Samore, 2002). Self-medication with antibiotics is among the means of their irrational use. As a basic medicine, people use antimicrobials, usually selfprescribed, for various kinds of infections. Soon, such unchecked use of antibiotics could lead to a 'preantibiotic era' until the discovery of penicillin, not just in humans but also in animals, when many disease infections would be almost impossible to treat again because of antimicrobial resistance (Okumura et al., 2002; Samaranayake and Johnson, 1999). Each country has its antimicrobial drug use policies and regulations, but its implementation is not always effective. Following numerous evidence-based advice and newly gained expertise or facts, this situation should improve.

[Citation: Khalid, S., Ali, Q., Hafeez, M.N., Malik A. (2021). Perception regarding self-medication of antibiotics in general public sector University of Southern Punjab: A comparison between medical and non-medical students. Biol. Clin. Sci. Res. J., 2021: 51. doi: https://doi.org/10.54112/bcsrj.v2021i1.51] 
For instance, in France, one of the leading countries in outpatient antibiotic use, more than half of the population expects an antibiotics prescription for the common cold (Harbarth et al., 2002). In developing countries such as Pakistan, this issue is in its worse form due to the poor economic condition of its inhabitants. Other developing countries are Trinidad and Tobago, where issues with self-medication have been reported. .(Awad et al., 2005; Parimi et al., 2004). However, developed countries are also effected from this problem and many studied have reported problem because of it in countries such as the USA, Spain, Russia, Greece and Israel (Grigoryan et al., 2006; Guillemot et al., 1998). Several antibiotics work to remove the symptoms of his disease from the point of view of the selfmedication user, but it is scientifically understood that if he takes large doses, he is responsible for side effects and the pathogen will become resistant to the body of the patient and more pathogenic (Guillemot et al., 1998; Okeke et al., 2005; WHO, 2001). In order to safely and efficiently alleviate symptoms without medical consultation, WHO supports selfmedication activities and to reduce the burden on health care facilities that are often understaffed and ineffective in rural and remote areas (Gonzales et al., 2001; WHO, 2001). The pattern of antibiotic use is based on public perceptions and information, particularly whether optimal doses are given and/or whether complete courses of therapy are taken (Laxminarayan et al., 2013; Van Boeckel et al., 2014). It was difficult for patients to understand the value of antibiotic doses or the patient age, the theory of resistance and the implications of such malpractice. Public knowledge of antibiotics is of particular significance in developing countries like Pakistan, where antibiotics are available without a prescription. When it comes to administering antibiotics to rationalise the usage and strengthen tolerance, research on people who know the antibiotic is important (Holmes et al., 2016; Silbergeld et al., 2008).

\section{Methodology}

\section{Area and Location}

The study area was a public sector the University of South Punjab, Khawaja Fareed University of Rahim Yar Khan. Raheem Yar Khan is located in the southeast of Punjab province, is about 700kmfrom Karachi with a population of 3434108 of which $30.6 \%$ were urban. The Khawaja Fareed University is a public sector university, which has more than Departments, Disciplines, Facilities and Centers.

\section{Objectives}

Objective may be general and specific. Selfmedication assessment by students from the publicsector university of Southern Punjab. To compare self-medication among university student studying in various departments.

\section{Study Design}

A cross-sectional study design was adopted to conduct this study.

\section{Study Population}

The target population was taken from university students who came to this university from different cities. Currently enrolled students were invited to participate in the study.

\section{Sampling Method}

A semi structured questionnaire developed and pilot tested by the principle investigator was used as sample.

\section{Sampling Procedure}

I. Inclusion Criteria

Inclusion criteria for the respondent of the study were as follows:

i. Students enrolled in Khawaja Fareed University, Rahim Yar khan (Medical, Law, CS, BBA, Commerce department).

ii. Students willing to participants in the study.

II. Exclusion Criteria

Exclusion criteria for the respondents of the study were as follows:

- Students who had already completed their education were not invited to participate in the study.

- Students who were not willing to participate in the study.

\section{Data Collection Tool}

The information was collected through a selfadministered questionnaire (tool). The questionnaire comprises four parts that include both Closed, Open Complete Problems. A first phase involved included demographic variables, such as ages, genders, and subject fields which have concerns about the policies and expertise of using antibiotics and on evidence, not just in violation. The second part comprised of a whole chain of land the nine questions related to the reason for self-medication, condition for selfmedication, commonly self-medicated antibiotics e.tc The third section contains three questions related to self-medication part of self-care, continues the selfmedication with antibiotic and advises selfmedication to your friends.

The last question had one question inquiring method about prevention of self-medication of antibiotics.

Reliability (internal consistency) testing of tool A pilot study was conducted and Cronbach's Alpha test conducted to evaluate the internal consistency of questionnaire, and alpha value was $0.65(\mathrm{n}=19)$.

[Citation: Khalid, S., Ali, Q., Hafeez, M.N., Malik A. (2021). Perception regarding self-medication of antibiotics in general public sector University of Southern Punjab: A comparison between medical and non-medical students. Biol. Clin. Sci. Res. J., 2021: 51. doi: https://doi.org/10.54112/bcsrj.v2021i1.51] 
Validity Testing (face and control testing)

Experts evaluated the data collection tool for its face and content validity.

\section{Data Analysis}

Using SPSS versions 15.0, and descriptive statistics all the data were analyzed (frequencies percentages, mean, median, standard derivation and IQR) were conducted to summarize data and Chi-square test was applied as inferential statistics. A P value than 0.05 was considered as statistical significance.

\section{Results}

\section{Descriptive Analysis}

Table 1 Section a (part 1) Demographic data of Gender, Age and Field of study of students

\begin{tabular}{llll}
\hline Variables & & Frequency & Percentage \\
\hline Gender & Male & 402 & 44.7 \\
& Female & 498 & 55.3 \\
& Total & 900 & 100 \\
Age & & (Mean) & (SD) \\
& & 20.7 & 12.2 \\
Field of & Medical & 450 & 50 \\
study & Non- & 450 & 50 \\
& medical & & \\
& Total & 900 & 100 \\
\hline
\end{tabular}

Demographic data was analyzed through descriptive statistics. Frequencies and percentages of variable were analyzed from which mean and standard deviation of variables obtained. The majority of the students (498) were female's. The students were from variety of disciplines participated in the study. Age of the students was also recorded the most significance age group was (20-21) years. About 50\% respondents were from medical discipline and $50 \%$ from Nonmedical disciplines (Table 1).

Table 2 Section A (part 2) knowledge of student about self-medication

\begin{tabular}{lrlll}
\hline \multicolumn{2}{l}{ Questions } & Response & Frequency & Percentage \\
\hline Do & you & Yes & 866 & 96.2 \\
know & what & No & 34 & 3.8 \\
is & & & &
\end{tabular}

Antibiotic?

$\begin{array}{llll} & \text { Total } & 900 & 100 \\ \text { Antibiotic } & \text { Yes } & 500 & 55.6 \\ \text { use without } & \text { No } & 400 & 44.4\end{array}$

consultation

of doctor.

Total $\quad 900 \quad 100$

Knowledge was also analyzed through descriptive statistics. 96.2\% students were aware of antibiotics and $3.8 \%$ were not known. Similarly, from analysis it was also known that $55.6 \%$ students use antibiotic without doctor consultation and $44.4 \%$ students do not use antibiotic without doctor consultation (Table 2).

\section{Inferential Analysis}

Inferential Analysis was done with the help of Pearson's Chi-squared test and obtained $\mathrm{P}$ values (Table 3).

Table 3 Section A (Part 1): knowledge of students about antibiotic with respect to gender

\begin{tabular}{|c|c|c|c|c|}
\hline Questions & Response & $\begin{array}{l}\text { Male } \\
\text { No\% }\end{array}$ & $\begin{array}{l}\text { Female } \\
\text { No\% }\end{array}$ & $\begin{array}{l}\mathrm{P} \\
\text { value }\end{array}$ \\
\hline Do you & Yes & $388(96$ & $478(96$. & \\
\hline know, what & & $.5)$ & 0) & .768 \\
\hline $\begin{array}{l}\text { is } \\
\text { antibiotic? }\end{array}$ & No & $14(3.5)$ & $20(4.0)$ & \\
\hline $\begin{array}{l}\text { Do you use } \\
\text { antibiotic }\end{array}$ & Yes & $\begin{array}{l}224(55 \\
.7)\end{array}$ & $\begin{array}{l}276(55 . \\
4)\end{array}$ & \\
\hline $\begin{array}{l}\text { without } \\
\text { doctor } \\
\text { consultatio } \\
\text { n. }\end{array}$ & No & $\begin{array}{l}178(44 \\
.3)\end{array}$ & $\begin{array}{l}222(44 . \\
6)\end{array}$ & .513 \\
\hline
\end{tabular}

\begin{tabular}{|c|c|c|c|c|}
\hline $\begin{array}{r}\text { Table } 4 \\
\text { students ab }\end{array}$ & $\begin{array}{l}\text { Selection } A \\
\text { out antibiot } \\
\text { and non-me }\end{array}$ & $\begin{array}{l}\text { Part 2): } k \\
\text { c with res } \\
\text { dical stud }\end{array}$ & $\begin{array}{l}\text { nowledge } \\
\text { pect to me } \\
\text { nts }\end{array}$ & \\
\hline Questions & Response & $\begin{array}{l}\text { Medical } \\
\text { No\% }\end{array}$ & $\begin{array}{l}\text { Non- } \\
\text { medical } \\
\text { No\% }\end{array}$ & $\begin{array}{l}P \\
\text { value }\end{array}$ \\
\hline Do you & Yes & $448(99$. & $418(92.9$ & \\
\hline know what & & & ) & $<0.00$ \\
\hline $\begin{array}{l}\text { is } \\
\text { antibiotics? }\end{array}$ & No & $2(0.4)$ & $32(7.1)$ & 1 \\
\hline $\begin{array}{l}\text { Do you use } \\
\text { antibiotic }\end{array}$ & Yes & $\begin{array}{l}\text { 256(56. } \\
9)\end{array}$ & $\begin{array}{l}244(54.2 \\
)\end{array}$ & \\
\hline $\begin{array}{l}\text { without } \\
\text { doctor } \\
\text { consultatio } \\
\text { n? }\end{array}$ & No & $\begin{array}{l}\text { 182(43. } \\
1)\end{array}$ & $\begin{array}{l}206(45.8 \\
)\end{array}$ & .318 \\
\hline $\begin{array}{l}\text { It is found th } \\
\text { had knowled } \\
\text { students }(92 . \\
(<0.001) \text { bet } \\
\text { Table } 5 \\
\text { practicin }\end{array}$ & $\begin{array}{l}\text { at more me } \\
\text { ge about ar } \\
\% \text { ) and ther } \\
\text { veen them (T } \\
\text { Section A ( } \\
\text { g the self-m }\end{array}$ & $\begin{array}{l}\text { ical field } \\
\text { tibiotics } t \\
\text { was sign } \\
\text { able 4). } \\
\text { art 3): } \mathbf{R e} \\
\text { dication }\end{array}$ & $\begin{array}{l}\text { students }(9 \\
\text { han non-m } \\
\text { ficant diffe } \\
\text { ason for no } \\
\text { f antibioti }\end{array}$ & $\begin{array}{l}6 \%) \\
\text { dical } \\
\text { ence }\end{array}$ \\
\hline Question & Response & Frequen & y $\quad$ Percer & age \\
\hline $\begin{array}{l}\text { What is the } \\
\text { reason for }\end{array}$ & $\begin{array}{l}\text { Wrong } \\
\text { drug }\end{array}$ & 316 & 35.1 & \\
\hline not & ADR's & 242 & 26.9 & \\
\hline practicing & Wrong & 188 & 20.9 & \\
\hline $\begin{array}{l}\text { the self- } \\
\text { medication }\end{array}$ & $\begin{array}{l}\text { diagnosis } \\
\text { Others }\end{array}$ & 154 & 17.1 & \\
\hline $\begin{array}{l}\text { of } \\
\text { antibiotics? }\end{array}$ & Total & 900 & 100 & \\
\hline
\end{tabular}

Through descriptive statistics, it was analyzed that $35.1 \%$ students were not practicing self-medication because of perception of wrong drug use, $26.9 \%$ due to expected adverse drug reaction, $20.9 \%$ due to

[Citation: Khalid, S., Ali, Q., Hafeez, M.N., Malik A. (2021). Perception regarding self-medication of antibiotics in general public sector University of Southern Punjab: A comparison between medical and non-medical students. Biol. Clin. Sci. Res. J., 2021: 51. doi: https://doi.org/10.54112/bcsrj.v2021i1.51] 
susceptibility of wrong diagnosis and $17.1 \%$ due to other reasons (Table 5).

Descriptive Analysis

Table 6 Section B (Part 1): Practice of selfmedication of antibiotics

\begin{tabular}{|c|c|c|c|}
\hline Questions & Response & Frequency & Percentage \\
\hline \multirow{3}{*}{$\begin{array}{l}\text { Do you } \\
\text { know the } \\
\text { active } \\
\text { ingredient } \\
\text { of } \\
\text { antibiotic } \\
\text { that you } \\
\text { self- } \\
\text { medicate? }\end{array}$} & Yes & 520 & 57.8 \\
\hline & No & 380 & 42.2 \\
\hline & Total & 900 & 100 \\
\hline \multirow[b]{2}{*}{$\begin{array}{l}\text { Do you } \\
\text { think that } \\
\text { antibiotic } \\
\text { can recover } \\
\text { any type of } \\
\text { infection? }\end{array}$} & Yes & 540 & 60 \\
\hline & No & 360 & 40 \\
\hline \multirow{3}{*}{$\begin{array}{l}\text { Do you } \\
\text { know any } \\
\text { idea in } \\
\text { which } \\
\text { disease } \\
\text { antibiotic } \\
\text { use? }\end{array}$} & $\begin{array}{l}\text { Total } \\
\text { Yes }\end{array}$ & & $\begin{array}{l}100 \\
73.3\end{array}$ \\
\hline & No & 240 & 26.7 \\
\hline & Total & 900 & 100 \\
\hline \multirow{3}{*}{$\begin{array}{l}\text { Do you } \\
\text { think that } \\
\text { self- } \\
\text { medication } \\
\text { with } \\
\text { antibiotic is } \\
\text { safe? }\end{array}$} & Yes & 468 & 52 \\
\hline & No & 432 & 48 \\
\hline & Total & 900 & 100 \\
\hline \multirow{3}{*}{$\begin{array}{l}\text { Have you } \\
\text { experience } \\
\text { any un- } \\
\text { expected } \\
\text { reaction } \\
\text { due to } \\
\text { antibiotic } \\
\text { use? }\end{array}$} & $\begin{array}{l}\text { Yes } \\
\text { No }\end{array}$ & $\begin{array}{l}218 \\
782\end{array}$ & $\begin{array}{l}75.8 \\
100\end{array}$ \\
\hline & & & \\
\hline & Total & 900 & 100 \\
\hline
\end{tabular}

Note:

Frequencies and percentage are based on observed values. Through descriptive statistics, data of the practice of self-medication of antibiotics were analyzed. $57.8 \%$ of students know the active ingredient of antibiotic, which they self-medicate, and $42.2 \%$ do not know the active ingredients of antibiotic that they self-medicate. $60 \%$ of students believe that antibiotic can recover any type of infection (Table 6). 52\% of students think selfmedication with an antibiotic is safe and $48 \%$ do not think so. $24.2 \%$ of students experienced adverse drug reaction and $75.8 \%$ remained unaware of the adverse drug reaction or did not experience.

Table 7 Section B (part 2): practice of selfmedication of antibiotics

\begin{tabular}{|c|c|c|c|}
\hline Questions & Response & Frequency & Percentage \\
\hline \multirow{8}{*}{$\begin{array}{l}\text { What is the } \\
\text { reason for } \\
\text { self- } \\
\text { medication } \\
\text { of } \\
\text { antibiotic? }\end{array}$} & Illness of & 52 & 20.7 \\
\hline & trivial & & \\
\hline & Pharma & 104 & 41.4 \\
\hline & knowledge & & \\
\hline & Save time & 62 & 24.7 \\
\hline & High fee & 26 & 10.4 \\
\hline & Privacy & 7 & 2.8 \\
\hline & Total & 450 & 100 \\
\hline \multirow{7}{*}{$\begin{array}{l}\text { What is the } \\
\text { source of } \\
\text { informatio } \\
\text { n about } \\
\text { antibiotic? }\end{array}$} & Old & 57 & 22.8 \\
\hline & prescription & & \\
\hline & Drug & 35 & 14 \\
\hline & advertise & & \\
\hline & Academic & 135 & 54 \\
\hline & Friends & 22 & 8.8 \\
\hline & Total & 450 & 100 \\
\hline \multirow{8}{*}{$\begin{array}{l}\text { Which } \\
\text { antibiotic } \\
\text { you use for } \\
\text { self- } \\
\text { medication } \\
?\end{array}$} & Amoxicillin & 55 & 22 \\
\hline & Ciprofloxaci & 33 & 13.2 \\
\hline & $\mathrm{n}$ & & \\
\hline & Erythromyci & 28 & 11.2 \\
\hline & $\mathrm{n}$ & & \\
\hline & Augmentin & 93 & 37.2 \\
\hline & Others & 38 & 15.2 \\
\hline & Total & 450 & 100 \\
\hline \multirow{6}{*}{$\begin{array}{l}\text { In which } \\
\text { condition } \\
\text { do you use } \\
\text { self- } \\
\text { medication } \\
\text { of } \\
\text { antibiotic? }\end{array}$} & Fever & 54 & 20.9 \\
\hline & Cough & 63 & 24.4 \\
\hline & Cold & 35 & 13.6 \\
\hline & Malaria & 5 & 1.9 \\
\hline & All & 100 & 38.1 \\
\hline & Total & 450 & 100 \\
\hline
\end{tabular}

The students were provided with possible options for the reason of use of self-medication of antibiotics. $41.4 \%$ students use to purchase self-selected antibiotics due to their pharma knowledge, $24.7 \%$ to save their time, $20.7 \%$ due to illness of trivial, $10.4 \%$ due to high consultant fee, $2.8 \%$ for keeping privacy. Students were provided with possible option for the source of information about antibiotic $54 \%$ students use academic knowledge, $22.8 \%$ use old prescriptions $14 \%$ use drug advertisement $8.8 \%$ seek information from their friends (Table 7). The students were asked to pick antibiotic from most commonly

[Citation: Khalid, S., Ali, Q., Hafeez, M.N., Malik A. (2021). Perception regarding self-medication of antibiotics in general public sector University of Southern Punjab: A comparison between medical and non-medical students. Biol. Clin. Sci. Res. J., 2021: 51. doi: https://doi.org/10.54112/bcsrj.v2021i1.51] 
used antibiotics about 37.2\% used Augmentin, 22\%

Amoxicillin, $\quad 13.2 \% \quad$ Ciprofloxacin, $11.2 \%$ Erythromycin and the remaining $15.2 \%$ use others. $24.4 \%$ students use in cough, $20.9 \%$ in fever, $13.6 \%$ in cold, $1.9 \%$ in malaria and $38.1 \%$ use antibiotics in all given conditions.

Table 8 Section B (part 2): practice of selfmedication of antibiotics with respect to gender

\begin{tabular}{|c|c|c|c|c|}
\hline Questions & Response & $\begin{array}{l}\text { Male } \\
\text { No\% }\end{array}$ & $\begin{array}{l}\text { Female } \\
\text { No\% }\end{array}$ & $\begin{array}{l}P \\
\text { value }\end{array}$ \\
\hline What is & Illness & $22(19$. & $30(22$ & .046 \\
\hline & trivial & 0) & 2) & \\
\hline reason & Pharmacologi & $41(35$. & $63(46$. & \\
\hline $\begin{array}{l}\text { for self- } \\
\text { medicatio }\end{array}$ & $\begin{array}{l}\text { cal } \\
\text { knowledge }\end{array}$ & 3) & 7) & \\
\hline $\begin{array}{l}n \quad \text { of } \\
\text { antibiotic }\end{array}$ & To save time & $\begin{array}{l}30(25 . \\
9)\end{array}$ & $\begin{array}{l}32(23 . \\
7)\end{array}$ & \\
\hline$?$ & $\begin{array}{l}\text { High } \\
\text { consultant fee }\end{array}$ & $\begin{array}{l}18(15 . \\
5)\end{array}$ & $8(5.9)$ & \\
\hline & Privacy & $5(4.3)$ & $2(1.5)$ & \\
\hline $\begin{array}{l}\text { What is } \\
\text { the }\end{array}$ & $\begin{array}{l}\text { Old } \\
\text { prescription }\end{array}$ & $\begin{array}{l}25(21 . \\
7)\end{array}$ & $\begin{array}{l}32(23 . \\
7)\end{array}$ & .708 \\
\hline source of & Drug & $18(15$. & $17(12$. & \\
\hline informati & advertise & 7) & 6) & \\
\hline on about & Academic & $60(52$. & $75(55$. & \\
\hline antibiotic & knowledge & 2) & 6) & \\
\hline$?$ & Friends & $\begin{array}{l}12(10 . \\
4)\end{array}$ & $10(7.4$ & \\
\hline Common & Amoxicillin & $29(25$. & $26(19$. & .090 \\
\hline ly used & & 0) & 3) & \\
\hline antibiotic & Ciprofloxacin & $10(8.6$ & $23(17$. & \\
\hline for self- & & ) & 0) & \\
\hline medicatio & & $15(12$. & $13(9.6$ & \\
\hline $\mathrm{n}$ & Erythromycin & 9) & ) & \\
\hline & Augmentin & $\begin{array}{l}38(32 . \\
8)\end{array}$ & $\begin{array}{l}56(41 . \\
5)\end{array}$ & \\
\hline & Others & $\begin{array}{l}23(19 . \\
8)\end{array}$ & $\begin{array}{l}15(11 . \\
1)\end{array}$ & \\
\hline $\begin{array}{l}\text { Common } \\
\text { condition }\end{array}$ & Fever & $\begin{array}{l}23(19 . \\
3)\end{array}$ & $\begin{array}{l}31(22 . \\
3)\end{array}$ & .461 \\
\hline in which & Cough & $27(22$. & $36(25$. & \\
\hline you use & & 7) & 9) & \\
\hline $\begin{array}{l}\text { self- } \\
\text { medicatio }\end{array}$ & Cold & $\begin{array}{l}19(16 . \\
0)\end{array}$ & $\begin{array}{l}16(11 . \\
5)\end{array}$ & \\
\hline$n \quad$ of & Malaria & $4(3.4)$ & $1(.7)$ & \\
\hline & All of these & $\begin{array}{l}46(38 . \\
7)\end{array}$ & $\begin{array}{l}54(38 . \\
8)\end{array}$ & \\
\hline
\end{tabular}

Note: Frequencies and percentage are based on observed values $\mathrm{P}$-value for the Chi-square test.

Results show that most female students are practicing self-medication because of sufficient pharmacological knowledge 63(43.7\%) and male students are practicing self-medication because of to

save time $30(25.9 \%$ ) (Table 8) so there is a significant difference (0.046) and explanation for self-medication between the activities of antibiotics Descriptive analysis

Table 9 Section C: Behavior of the student toward the self-medication of antibiotics

\begin{tabular}{lrlll}
\hline \multicolumn{2}{c}{ Questions } & Response & Frequency & Percentage \\
\hline Do & you & Yes & 171 & 38 \\
think & that & No & 150 & 33.3 \\
self- & & Total & 450 & 100
\end{tabular}

medication

is a part of

self-care?

$\begin{array}{lllll}\text { Do } & \text { you } & \text { Yes } & 97 & 21.6 \\ \text { think } & \text { you } & \text { No } & 220 & 48.0\end{array}$

\begin{tabular}{|c|}
\hline hould \\
\hline
\end{tabular}

continue

with or

start self-

medication

of

antibiotic?

Do you Yes $\quad 96 \quad 21.3$

$\begin{array}{llll}\text { advise self- } & \text { No } & 319 & 70.9\end{array}$

medication Total $\quad 450 \quad 100$

of

antibiotic

to your

friends?

Note: frequencies and percentage are based on observed values

$38 \%$ of students show a positive attitude towards self-medication and $33 \%$ do not think that selfmedication is part of self-care. $21.6 \%$ think that they should continue with self-medication of antibiotics and $48 \%$ think do not continue with self-medication of antibiotic (Table 9). 21.3\% of students usually advise the self-medication of antibiotics to their friends and $70.9 \%$ do not advise.

Table 10 Section C: Attitude of the students toward the self-medication of Antibiotics with respect to gender

\begin{tabular}{|c|c|c|c|c|}
\hline Questions & Response & $\begin{array}{l}\text { Male } \\
\text { No\% }\end{array}$ & $\begin{array}{l}\text { Female } \\
\text { No\% }\end{array}$ & $\begin{array}{l}\mathrm{P} \\
\text { value }\end{array}$ \\
\hline Do you & Yes & $81(40.3)$ & $90(36.1)$ & 0.164 \\
\hline think that & No & $69(34.3)$ & $81(32.5)$ & \\
\hline $\begin{array}{l}\text { self- } \\
\text { medication } \\
\text { is a part of } \\
\text { self-care? }\end{array}$ & $\begin{array}{l}\text { Not } \\
\text { sure }\end{array}$ & $51(25.4)$ & $78(31.3)$ & \\
\hline Do you & Yes & $45(24.4)$ & $52(20.9)$ & .180 \\
\hline think & No & $93(46.3)$ & $127(51.0)$ & \\
\hline $\begin{array}{l}\text { should } \\
\text { continue }\end{array}$ & $\begin{array}{l}\text { Not } \\
\text { sure }\end{array}$ & $63(31.3)$ & $70(28.1)$ & \\
\hline
\end{tabular}

[Citation: Khalid, S., Ali, Q., Hafeez, M.N., Malik A. (2021). Perception regarding self-medication of antibiotics in general public sector University of Southern Punjab: A comparison between medical and non-medical students. Biol. Clin. Sci. Res. J., 2021: 51. doi: https://doi.org/10.54112/bcsrj.v2021i1.51] 


\begin{tabular}{lllll}
\hline $\begin{array}{l}\text { or start } \\
\text { with self- }\end{array}$ & & & & \\
medication & & & & \\
of & & & & \\
antibiotic? & & & & \\
Do you & Yes & $53(26.4)$ & $43(17.3)$ & 0.019 \\
advise & No & $129(64.2)$ & $190(76.3)$ & \\
self- & Not & $19(9.5)$ & $16(6.4)$ & \\
medication & sure & & & \\
of & & & & \\
antibiotic & & & & \\
to your & & & & \\
friends? & & & &
\end{tabular}

Note: Frequencies and percentage are based on observed values $\mathrm{P}$ value for Chi square test (Table 10).

Table 11 Section D: perception of students regarding method to prevent self-medication of antibiotics

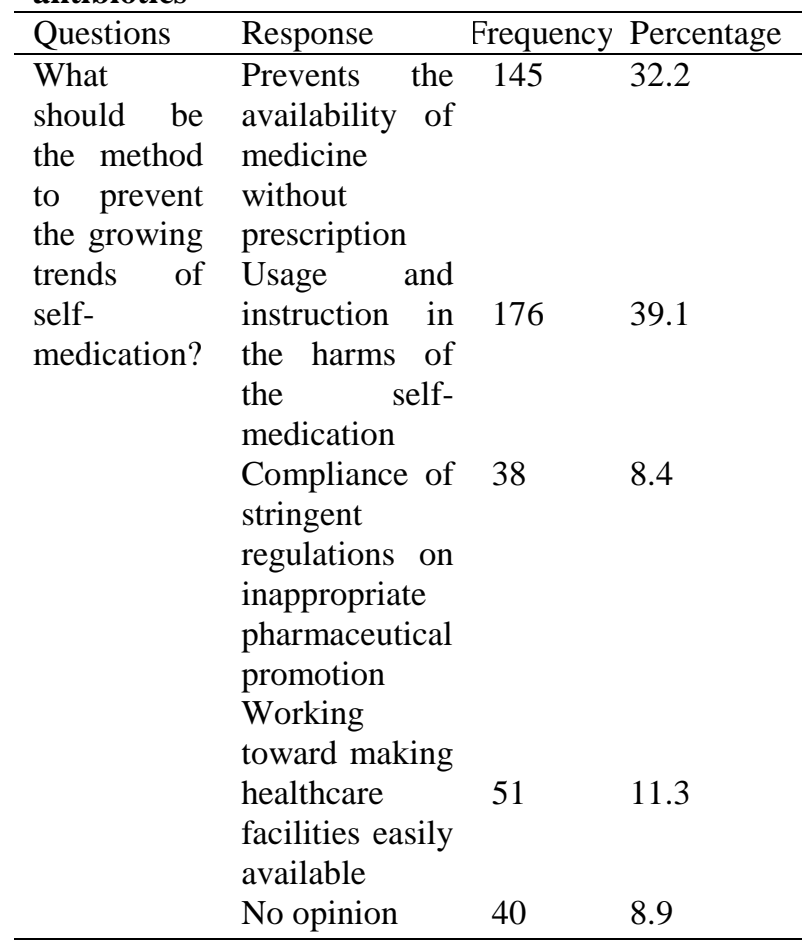

The students were asked possible options regarding the method to prevent the growing trend of selfmedication. $39.1 \%$ students agreed with awareness or education regarding harms of self-medication, $32.2 \%$ students agreed to prevent the availability of medicine without a prescription (Table 11), 11.3\% agreed with working toward making healthcare facilities easily available, $8.4 \%$ agreed with enforcing the strict rule regarding misleading pharmaceutical promotion and $8.9 \%$ have no opinion about this.
Table 12 section D: Students understanding of the technique for preventing self-medication of antibiotics with respect to gender

\begin{tabular}{|c|c|c|c|c|}
\hline Question & Response & $\begin{array}{l}\text { Male } \\
\text { No\% }\end{array}$ & $\begin{array}{l}\text { Female } \\
\text { No\% }\end{array}$ & $\mathrm{P}$ value \\
\hline $\begin{array}{l}\text { Method to } \\
\text { discourage } \\
\text { the } \\
\text { increasing } \\
\text { trend of } \\
\text { self- } \\
\text { medication }\end{array}$ & $\begin{array}{l}\text { Prevent the } \\
\text { supply of } \\
\text { medication } \\
\text { without } \\
\text { prescription } \\
\text { Awareness or } \\
\text { education } \\
\text { regarding } \\
\text { harms of self- } \\
\text { medication } \\
\text { Enforcing the } \\
\text { strict rule } \\
\text { regarding } \\
\text { misleading } \\
\text { pharmaceutical } \\
\text { promotion } \\
\text { Make health- } \\
\text { care facilities } \\
\text { easily } \\
\text { available } \\
\text { No opinion }\end{array}$ & $57(28.4)$ & $107(43.0)$ & 0.001 \\
\hline
\end{tabular}

Note: Frequencies and percentage are based on observed values P-value for Chi-square test

Study shows that most pharmacy students are practicing self-medication because of sufficient pharmacological knowledge $76(55.1 \%)$ and nonpharmacy students are practicing self-medication because of to save time $33(29 \%)$ so there is a significant difference $(<0.001)$ between the reasons for practicing self-medication of antibiotics (Table 12). More female students have the perception that growing trend of self-medication of antibiotics can be prevented by awareness or education regarding harms of self-medication 107(43.05) and male students have the perception that it can be controlled by preventing the supply of medication without prescription $57(28.4 \%)$.

\section{Discussion}

Our results are confirming the expectations are strong with antibiotics by our public sector the University of Southern Punjab with considerable resources, selfassignments of antibiotics are practicable (they are legally available over the counter). Antibiotics primarily given by physicians will be preserved in the absence of medicinal consultation and added to the medicines later. With their equivalents, they are simpler antibiotics that can be obtained over the Internet. Many people know about antibiotic and they use antibiotic without doctor consultation. This study

[Citation: Khalid, S., Ali, Q., Hafeez, M.N., Malik A. (2021). Perception regarding self-medication of antibiotics in general public sector University of Southern Punjab: A comparison between medical and non-medical students. Biol. Clin. Sci. Res. J., 2021: 51. doi: https://doi.org/10.54112/bcsrj.v2021i1.51] 
has been carried out to analyze the understanding, approach, and actions of medical and non-medical learners of the State sector residency. The prevalence of self-medication is worrying about incipient youth education in Pakistan. It is in contradiction with the male students that female students engaged in selfmedication rather than male. This study emphasized in research, similar results were made (Grigoryan et al., 2006; Holmes et al., 2016; Richman et al., 2001). In this research, self-medication frequencies among university studies that are both medical and nonmedical very high; similar findings can be assessed between the studies on research carried out with university students of Karachi with the individual drug data made to the analysis they conducted in India, comparable with what was found in Tamil Nadu in Spain (Al-Azzam et al., 2007; Grigoryan et al., 2007). According to our study, most of the pharmacy students know the active ingredient of antibiotic that they self-medicate. In the present study, Augmentin and Amoxicillin are most commonly self-medicated antibiotics. Another study was performed in Jordan and Sweden showed that Amoxicillin was the most in use antibiotic for selfmedication (Morgan et al., 2011; Stratchounski et al., 2003). According to this study, half of the respondents think that the self-medication of antibiotic is safe and most of the respondents did not experience any unexpected reaction due to the selfmedication of the antibiotics. The most participants involved in our study reported that they think any antibiotic can recover any type of infection. A research performed in Yogyakarta city Indonesia showed that only a few participants believe that antibiotics can cure any disease (Al-Azzam et al., 2007; Davey et al., 2006). As the students of this study have reported, Cough has been the primary source of treatment with antibiotics. An in-India trial study identified that throat loss is a main indicator of antibiotic (Huttner et al., 2010; Laxminarayan et al., 2013). Another study performed in Jordan population showed that the condition for which antibiotics were self-medicated, pharyngitis was most prevalent followed by flu (common cold) and rhinorrhea (AlAzzam et al., 2007; Ruiz, 2010). In studies from Nigeria (Grigoryan et al., 2007; Napolitano et al., 2013). Diarrhea and gastro-intestinal infections have been identified as the most frequent marker for use, while Turkish or Greek have been reported as the most widespread (Laxminarayan et al., 2013). The most popular indication for the antibiotics was a common cold. In this study, respondents thought selfdrugs were part of self-care, which is marginally lower than that recorded trial in India (Van Boeckel et al., 2014). Most of the participants involved in our study though that they should not continue with or start self-medication of antibiotics while few wished to continue with or start self-medication with antibiotics. However, study performed in India showed that $50 \%$ of the participants were wishing to continue with or start self-medication with antibiotics (Llor and Bjerrum, 2014; Marston et al., 2016). In addition, awareness or understanding about the illness and strict policies for stopping the pharmaceutical drug without the treatment has emerged as the response to preventing the increasingly increasing transition towards without prescription medication. The comparison work in our study conducted in India showed that pointed steps were appropriate to prevent supplies of prescribed by avoiding rising phenomena in self prescription (Bryce et al., 2016; Exner et al., 2017). For the education of young people, particularly women, serious steps have to be taken. This is the only way miss-use of antibiotics can be minimized

\section{Recommendation \\ Practice}

- Prevent the supply of medicine without prescription.

- Health and knowledge about the consequences of self-medicating.

- In our local environment, a reevaluation of the purpose and scope of self-medication is given.

- The safe use of antibiotics needs tighter regulation over the marketing of antibiotic agents and helping to encourage them.

\section{Policy}

- The government should enforce a strict rule regarding misleading pharmaceutical advertising.

- The government should make policies regarding work together making healthcare facilities easily available.

- The government should take serious actions towards making policies to prevent the growing trends of self-medication of antibiotics.

\section{Future Research}

This study has also opened a gateway for future research

- Future research should be on resistance developed due to self-medication of antibiotic and other harms related to self-medication of antibiotics.

- Further studies are essential to evaluate the impacts of self-medication of antibiotics on the health of students 
- It would also be informative to know the factors associated with the self-medication of antibiotics.

- Further research may also focus on the influence of family on the self-medication of antibiotics.

- Further research may also focus on the economic factors that are associated with the selfmedication of antibiotics.

- Developing a sustainable prevention program is important to reduce antibiotic mental perceptions and raise public awareness of the possibility of improper application of antibiotics.

\section{Conclusion}

From the study, it can be concluded that the trend of miss-use of antibiotics are very high in both medical and non-medical students and necessary steps, as mentioned above, should be taken to prevent the accelerated antibiotics resistance just due to lack of information.

\section{Conflict of interest}

The authors declared absence of any conflict of interest.

\section{Reference}

Al-Azzam, S. I., Al-Husein, B. A., Alzoubi, F., and Masadeh, M. M. (2007). Self-medication with antibiotics in Jordanian population. International journal of occupational medicine and environmental health 20, 373.

Awad, A., Eltayeb, I., Matowe, L., and Thalib, L. (2005). Self-medication with antibiotics and antimalarials in the community of Khartoum State, Sudan. J Pharm Pharm Sci 8, 326-331.

Bronzwaer, S. (2002). European Antimicrobial Resistance Surveillance System. A European study on the relationship between antimicrobial use and antimicrobial resistance. Emerg Infect Dis 8, 278-282.

Bryce, A., Hay, A. D., Lane, I. F., Thornton, H. V., Wootton, M., and Costelloe, C. (2016). Global prevalence of antibiotic resistance in paediatric urinary tract infections caused by Escherichia coli and association with routine use of antibiotics in primary care: systematic review and meta-analysis. bmj 352, i939.

Davey, P., Brown, E., Fenelon, L., Finch, R., Gould, I., Holmes, A., Ramsay, C., Taylor, E., Wiffen, P., and Wilcox, M. (2006). Systematic review of antimicrobial drug prescribing in hospitals. Emerging infectious diseases 12, 211.

Exner, M., Bhattacharya, S., Christiansen, B., Gebel, J., Goroncy-Bermes, P., Hartemann, P., Heeg, P., Ilschner, C., Kramer, A., and Larson, E. (2017). Antibiotic resistance: What is so special about multidrug-resistant Gramnegative bacteria? GMS hygiene and infection control 12.

Gonzales, R., Bartlett, J. G., Besser, R. E., Cooper, R. J., Hickner, J. M., Hoffman, J. R., and Sande, M. A. (2001). Principles of appropriate antibiotic use for treatment of acute respiratory tract infections in adults: background, specific aims, and methods. Annals of internal medicine 134, 479-486.

Goossens, H., Ferech, M., Vander Stichele, R., Elseviers, M., and Group, E. P. (2005). Outpatient antibiotic use in Europe and association with resistance: a cross-national database study. The Lancet 365, 579-587.

Grigoryan, L., Burgerhof, J. G., Haaijer-Ruskamp, F. M., Degener, J. E., Deschepper, R., Monnet, D. L., Di Matteo, A., Scicluna, E. A., Bara, A.C., and Lundborg, C. S. (2007). Is selfmedication with antibiotics in Europe driven by prescribed use? Journal of Antimicrobial Chemotherapy 59, 152-156.

Grigoryan, L., Haaijer-Ruskamp, F. M., Burgerhof, J. G., Mechtler, R., Deschepper, R., TambicAndrasevic, A., Andrajati, R., Monnet, D. L., Cunney, R., and Di Matteo, A. (2006). Selfmedication with antimicrobial drugs in Europe. Emerging infectious diseases 12, 452.

Guillemot, D., Carbon, C., Balkau, B., Geslin, P., Lecoeur, H., Vauzelle-Kervroëdan, F., Bouvenot, G., and Eschwége, E. (1998). Low dosage and long treatment duration of $\beta$ lactam: risk factors for carriage of penicillinresistant Streptococcus pneumoniae. Jama 279, 365-370.

Harbarth, S., Albrich, W., and Brun-Buisson, C. (2002). Outpatient antibiotic use and prevalence of antibiotic-resistant pneumococci in France and Germany: a sociocultural perspective. Emerging infectious diseases $\mathbf{8}$, 1460.

Holmes, A. H., Moore, L. S., Sundsfjord, A., Steinbakk, M., Regmi, S., Karkey, A., Guerin, P. J., and Piddock, L. J. (2016). Understanding the mechanisms and drivers of antimicrobial resistance. The Lancet 387, 176-187.

Huttner, B., Goossens, H., Verheij, T., and Harbarth, S. (2010). Characteristics and outcomes of public campaigns aimed at improving the use of antibiotics in outpatients in high-income countries. The Lancet infectious diseases $\mathbf{1 0}$, 17-31.

Johnston, A. (1998). Use of antimicrobial drugs in veterinary practice. Bmj 317, 665-667.

[Citation: Khalid, S., Ali, Q., Hafeez, M.N., Malik A. (2021). Perception regarding self-medication of antibiotics in general public sector University of Southern Punjab: A comparison between medical and non-medical students. Biol. Clin. Sci. Res. J., 2021: 51. doi: https://doi.org/10.54112/bcsrj.v2021i1.51] 
Laxminarayan, R., Duse, A., Wattal, C., Zaidi, A. K., Wertheim, H. F., Sumpradit, N., Vlieghe, E., Hara, G. L., Gould, I. M., and Goossens, H. (2013). Antibiotic resistance - the need for global solutions. The Lancet infectious diseases 13, 1057-1098.

Lipsitch, M., and Samore, M. H. (2002). Antimicrobial use and antimicrobial resistance: a population perspective. Emerging infectious diseases 8, 347.

Llor, C., and Bjerrum, L. (2014). Antimicrobial resistance: risk associated with antibiotic overuse and initiatives to reduce the problem. Therapeutic advances in drug safety 5, 229241.

Marston, H. D., Dixon, D. M., Knisely, J. M., Palmore, T. N., and Fauci, A. S. (2016). Antimicrobial resistance. Jama 316, 11931204.

Morgan, D. J., Okeke, I. N., Laxminarayan, R., Perencevich, E. N., and Weisenberg, S. (2011). Non-prescription antimicrobial use worldwide: a systematic review. The Lancet infectious diseases 11, 692-701.

Napolitano, F., Izzo, M. T., Di Giuseppe, G., and Angelillo, I. F. (2013). Public knowledge, attitudes, and experience regarding the use of antibiotics in Italy. PloS one 8, e84177.

Okeke, I. N., Laxminarayan, R., Bhutta, Z. A., Duse, A. G., Jenkins, P., O'Brien, T. F., PablosMendez, A., and Klugman, K. P. (2005). Antimicrobial resistance in developing countries. Part I: recent trends and current status. The Lancet infectious diseases 5, 481493.

Okumura, J., Wakai, S., and Umenai, T. (2002). Drug utilisation and self-medication in rural communities in Vietnam. Social science \& medicine 54, 1875-1886.

Parimi, N., Pereira, L. M. P., and Prabhakar, P. (2004). Caregivers' practices, knowledge and beliefs of antibiotics in paediatric upper respiratorytract infections in Trinidad and Tobago: a cross-sectional study. BMC family practice 5, 28.

\section{(cc) (i) \&}

Open Access This article is licensed under a Creative Commons Attribution 4.0 International License, which permits use, sharing, adaptation, distribution and reproduction in any medium or format, as long as you give appropriate credit to the original author(s) and the source, provide a link to the Creative Commons licence, and
Picazo, J. J., Pérez-Cecilia, E., and Herreras, A. (2003). Respiratory infections outside the hospital. DIRA study. Enfermedades infecciosas y microbiologia clinica 21, 410416.

Richman, P. B., Garra, G., Eskin, B., Nashed, A. H., and Cody, R. (2001). Oral antibiotic use without consulting a physician: a survey of ED patients. The American journal of emergency medicine 19, 57-60.

Ruiz, M. E. (2010). Risks of self-medication practices. Current drug safety 5, 315-323.

Samaranayake, L., and Johnson, N. (1999). Guidelines for the use of antimicrobial agents to minimise development of resistance: FDI Commission. International dental journal 49, 189-195.

Silbergeld, E. K., Graham, J., and Price, L. B. (2008). Industrial food animal production, antimicrobial resistance, and human health. Annu. Rev. Public Health 29, 151-169.

Smith, R. D., Coast, J., Millar, M. R., Wilton, P., and Karcher, A.-M. (2001). Interventions against antimicrobial resistance: A review of the literature and exploration of modelling costeffectiveness. In "Geneva: Global Forum for Health Research". Citeseer.

Stratchounski, L., Andreeva, I., Ratchina, S., Galkin, D., Petrotchenkova, N., Demin, A., Kuzin, V., Kusnetsova, S., Likhatcheva, R., and Nedogoda, S. (2003). The inventory of antibiotics in Russian home medicine cabinets. Clinical infectious diseases 37, 498-505.

Van Boeckel, T. P., Gandra, S., Ashok, A., Caudron, Q., Grenfell, B. T., Levin, S. A., and Laxminarayan, R. (2014). Global antibiotic consumption 2000 to 2010: an analysis of national pharmaceutical sales data. The Lancet infectious diseases 14, 742-750.

WHO (2001). "WHO global strategy for containment of antimicrobial resistance." World Health Organization.

indicate if changes were made. The images or other third party material in this article are included in the article's Creative Commons licence, unless indicated otherwise in a credit line to the material. If material is not included in the article's Creative Commons licence and your intended use is not permitted by statutory regulation or exceeds the permitted use, you will need to obtain permission directly from the copyright holder. To view a copy of this licence, visit http://creativecommons.org/licenses/by/4.0/. (C) The Author(s) 2021

[Citation: Khalid, S., Ali, Q., Hafeez, M.N., Malik A. (2021). Perception regarding self-medication of antibiotics in general public sector University of Southern Punjab: A comparison between medical and non-medical students. Biol. Clin. Sci. Res. J., 2021: 51. doi: https://doi.org/10.54112/bcsrj.v2021i1.51] 